\title{
Molt-inhibiting hormone stimulates vitellogenesis at advanced ovarian developmental stages in the female blue crab, Callinectes sapidus 2: novel specific binding sites in hepatopancreas and CAMP as a second messenger
}

\author{
Nilli Zmora ${ }^{1}$, Amir Sagi ${ }^{2}$, Yonathan Zohar $^{1}$ and J Sook Chung*1
}

Address: ${ }^{1}$ Center of Marine Biotechnology, University of Maryland Biotechnology Institute, 701 E Pratt St Columbus Center, Suite 236, Baltimore, MD 21202, USA and 2Department of Life Sciences and the National Institute for Biotechnology in the Negev, Ben Gurion University, Beer Sheva, Israel

Email: Nilli Zmora - zmora@umbi.umd.edu; Amir Sagi - sagia@bgu.ac.il; Yonathan Zohar - zohar@umbi.umd.edu; J

Sook Chung* - chung@comb.umbi.umd.edu

* Corresponding author

Published: 7 July 2009

Saline Systems 2009, 5:6 doi:10.1186/1746-1448-5-6

This article is available from: http://www.salinesystems.org/content/5/I/6

(c) 2009 Zmora et al; licensee BioMed Central Ltd.

This is an Open Access article distributed under the terms of the Creative Commons Attribution License (http://creativecommons.org/licenses/by/2.0), which permits unrestricted use, distribution, and reproduction in any medium, provided the original work is properly cited.
Received: 9 March 2009

Accepted: 7 July 2009

\begin{abstract}
The finding that molt-inhibiting hormone $(\mathrm{MIH})$ regulates vitellogenesis in the hepatopancreas of mature Callinectes sapidus females, raised the need for the characterization of its mode of action. Using classical radioligand binding assays, we located specific, saturable, and non-cooperative binding sites for $\mathrm{MIH}$ in the $\mathrm{Y}$-organs of juveniles (J-YO) and in the hepatopancreas of vitellogenic adult females. MIH binding to the hepatopancreas membranes had an affinity 77 times lower than that of juvenile $\mathrm{YO}$ membranes ( $\mathrm{K}_{\mathrm{D}}$ values: $3.22 \times 10^{-8}$ and $4.19 \times 10^{-10} \mathrm{M} / \mathrm{mg}$ protein, respectively). The number of maximum binding sites $\left(B_{M A X}\right)$ was approximately two times higher in the hepatopancreas than in the YO ( $B_{\text {MAX }}$ values: $9.24 \times 10^{-9}$ and $4.8 \times 10^{-9} \mathrm{M} / \mathrm{mg}$ protein, respectively). Furthermore, MIH binding site number in the hepatopancreas was dependent on ovarian stage and was twice as high at stage 3 than at stages 2 and I. SDS-PAGE separation of [|25|] MIH or [125|] crustacean hyperglycemic hormone $(\mathrm{CHH})$ crosslinked to the specific binding sites in the membranes of the J-YO and hepatopancreas suggests a molecular weight of $\sim 5 \mathrm{I} \mathrm{kDa}$ for a MIH receptor in both tissues and a molecular weight of $\sim 6 \mathrm{I} \mathrm{kDa}$ for a $\mathrm{CHH}$ receptor in the hepatopancreas. The use of an in vitro incubation of hepatopancreas fragments suggests that $\mathrm{MIH}$ probably utilizes CAMP as a second messenger in this tissue, as CAMP levels increased in response to MIH. Additionally, 8-Bromo-cAMP mimicked the effects of MIH on vitellogenin $(V t G)$ mRNA and heterogeneous nuclear (hn) VtG RNA levels. The results imply that the functions of MIH in the regulation of molt and vitellogenesis are mediated through tissue specific receptors with different kinetics and signal transduction. $\mathrm{MIH}$ ability to regulate vitellogenesis is associated with the appearance of MIH specific membrane binding sites in the hepatopancreas upon pubertal/final molt.
\end{abstract}

\section{Background}

The X-organ in the eyestalks of crustaceans produces a family of crustacean hyperglycemic hormone $(\mathrm{CHH})$ neu- ropeptides unique to arthropods. The CHH family members in crustaceans $(\mathrm{CHH}$, molt-inhibiting hormone $(\mathrm{MIH})$, mandibular organ-inhibiting hormone (MOIH), 
and gonad/vitellogenesis-inhibiting hormone (GIH/ $\mathrm{VIH})$ ), are involved in the regulation of a variety of physiological processes [1-6]. It has been established that individual $\mathrm{CHH}$ are multifunctional, having specific binding sites in multiple target tissues $[7,8]$. More specifically, in addition to its primary hyperglycemic action [9], $\mathrm{CHH}$ inhibits ecdysteroidogenesis [10]; regulates water uptake during ecdysis [6]; and inhibits methionine incorporation in ovarian fragments, in vitro [11]. It was recently demonstrated that in addition to its traditional molt inhibiting role, MIH is also involved in the regulation of vitellogenesis in the mature female Callinectes sapidus [12] and in Metapenaeus ensis [13]. Since specific hormonal functions are accomplished by neuropeptides and their corresponding receptors [14], efforts have been made to identify and characterize the $\mathrm{CHH}$ neuropeptides family of receptors by means of binding kinetics [15-18], signal transduction [15,19-27], and cloning studies [28-31]. However, to date, the mechanisms by which the multiple functionality of these neuropeptides is being executed, are not fully understood.

MIH exerts its molt inhibiting activity on the Y-organs (YO) through the suppression of ecdysteroid synthesis and secretion [32-36] via the down-regulation of protein synthesis $[19,22]$. It has been reported that MIH binds exclusively to a YO membrane receptor with high affinity in a specific, displaceable, and saturable manner [16,17]. Attempts to define the mechanism of $\mathrm{MIH}$ signaling revealed changes in YO responsiveness throughout a molt cycle $[23,37,38]$. While MIH titers in the hemolymph and the number of binding sites of MIH in the YO of Carcinus maenas remained unchanged throughout a molt cycle, the level of cGMP responding to MIH in this tissue was greater at intermolt than at premolt stages [38]. This was further supported by the finding in Procambarus clarkii that phosphodiesterase activity in the YO at intermolt is markedly low, resulting in an extended cyclic nucleotide life span and in turn, higher levels [23].

It has been reported that $\mathrm{MIH}$ and $\mathrm{CHH}$ act via cGMP as a primary second messenger [15,23,26-28,37-39] although the involvement of CAMP, or both cAMP and CGMP [25] was also suggested. The large increase in cGMP production in the YO in response to MIH of C. sapidus [23] and the stimulation of cGMP in many tissues by $\mathrm{CHH}$ in $C$. maenas [15] have implicated a potential involvement of nitric oxide $\left(\mathrm{NO}^{-}\right)$, soluble guanylate cyclases [20], or membrane guanylate cyclase type receptors $[28,31,40]$. However, the structural characterization of a receptor for the CHH family of neuropeptides has not yet been elucidated in crustaceans nor in insects [41].

Ovarian development in crustaceans is controlled by neurohormones $[42,43]$. The inhibition of vitellogenesis by sinus gland factors is described in many species [3,44,45], while gonad stimulatory activity originates in the eyestalk, brain, and thoracic ganglia $[13,46,47]$. Overall, it appears that inhibition and stimulation are mediated by neuropeptides of the $\mathrm{CHH}$ family [13,44,45,47-53], with one exception that attributes the stimulatory action to a small peptide of 1000-2000 Da [54]. Further, a study in Marsupenaeus japonicus suggests that vitellogenic inhibition is modulated by $\mathrm{Ca}^{2+}$, cAMP, cGMP, and protein kinase $\mathrm{C}$ [24]. Much work is still required, however, to define the exact second messengers and the signal transduction pathways downstream of the neuropeptides that control vitellogenesis in crustaceans.

We have recently reported that $\mathrm{MIH}$ levels in the hemolymph of female $C$. sapidus are correlated with vitellogenic activity, i.e., higher at mid-vitellogenic than at previtellogenic stage. Furthermore, by the incubation of hepatopancreas fragments in vitro, we demonstrated that MIH acts directly in an ovarian stage dependent manner on the hepatopancreas where it stimulates mRNA, heterogeneous nuclear RNA of vitellogenin ( $h n V t G$ RNA = the newly transcribed yet unprocessed nuclear $V t G$ mRNA) and $V t G$ translation [12]. Consequently, we proposed that $\mathrm{MIH}$ has a regulatory role in vitellogenesis of the adult female, in addition to its prototypical molt inhibitory function. This fact imposed a re-examination of the accepted paradigm that MIH binds exclusively to the membranes of YO $[16,17]$ by verifying the presence of a specific receptor for $\mathrm{MIH}$ in the hepatopancreas of the female C. sapidus.

In the current study, we employed a classical radioligand binding assay to 1) locate and characterize specific binding sites of $\mathrm{MIH}$ in hepatopancreatic membranes of vitellogenic females, and 2) determine the molecular weights of $\mathrm{MIH}$ receptors in the membranes of hepatopancreas and the YO. In addition, we also examined the second messenger of MIH in hepatopancreas using an in vitro incubation assay and radioimmunoassays (RIA). The YO responded to MIH by elevating cGMP levels, while the hepatopancreas responded by increasing cAMP production. Altogether, our results indicate that MIH acts on the YO and the hepatopancreas via a tissue specific receptor.

\section{Results \\ MIH binding to the YO membranes}

To determine the maximal number of binding sites of $\mathrm{MIH}$ in the membranes of the YO, $50 \mu \mathrm{g}$ of membrane proteins were incubated with [125I] MIH from 0.15 to 12.3 $\mathrm{nM}$. The non-specific binding was determined using recombinant $\mathrm{MIH}(\mathrm{rMIH})$ due to the limited amount of native MIH (nMIH). The rMIH was as potent as $\mathrm{nMIH}$ in cGMP production in the $\mathrm{YO}$ in vitro (unpublished results) and produced the same $\mathrm{EC}_{50}$ value in a specific RIA using antibody raised against rMIH [12]. As shown in Fig. 1A, 
A

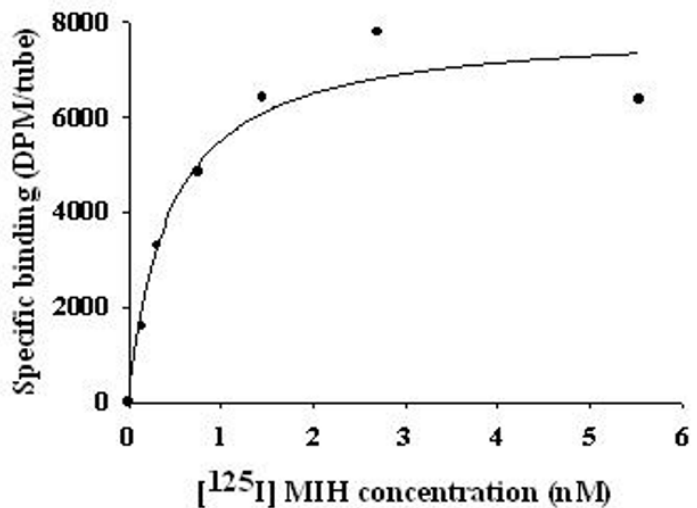

B

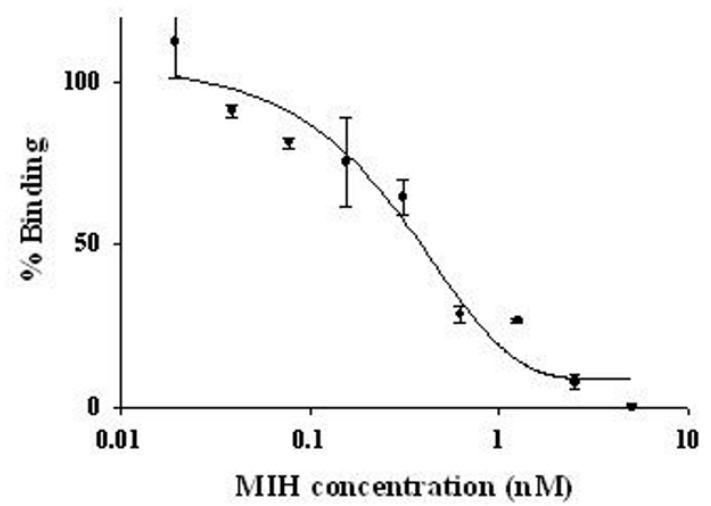

Figure I

Saturation curve (A) and displacement curve (B) of ['25I] MIH to the membranes of $Y O$ of juvenile $C$. sapdius. Bound $\left.\left.{ }^{125}\right]\right]$ MIH was displaced with unlabelled rMIH. The data are presented as mean \pm SEM of the triplicates.

the binding sites were saturable with a $K_{D}$ value of $4.19 \times$ $10^{-10} \mathrm{M} / \mathrm{mg}$ protein and a $\mathrm{B}_{\mathrm{MAX}}$ value of $4.8 \times 10^{-9} \mathrm{M} / \mathrm{mg}$ protein. Labeled and bound MIH was displaced with cold rMIH [12] at concentrations ranging from $24.4 \mathrm{pM}$ to 10 $\mathrm{nM}$ (Fig. $1 \mathrm{~B}$ ) with an $\mathrm{EC}_{50}$ value of $0.67 \mathrm{nM}$. A displacement study was carried out on YO membranes using cold $\mathrm{nMIH}$, resulting in a similar $\mathrm{EC}_{50}$ value of $0.66 \mathrm{nM}$. The non-specific binding in these experiments was 20-30\% of the total binding.

\section{MIH binding to the hepatopancreas membranes}

Membranes $(100 \mu \mathrm{g})$ of hepatopancreas at ovarian stages 1 to 3 and gills, abdominal muscle, YO and ovaries that were pooled from five females at each ovarian stage were incubated with 0.4 pmol [125I] MIH (263,000 DPM) with or without an excess of 20 pmol unlabelled rMIH. Hepatopancreas membranes prepared from five adult males and from juveniles were also tested, with juvenile YO (J-YO) membranes serving as a reference control. Specific binding of MIH was found only in mature female hepatopancreas among the tissues tested. MIH binding at ovarian stage 3 was two times higher than in stage 1 and comprised $~ 40 \%$ of the J-YO control (Fig. 2A). MIH binding to the $\mathrm{YO}$ of mature females at stage 3 was equal to that of juveniles (not shown in the figure). The same membranes were tested for [125I] CHH binding by incubating $100 \mu \mathrm{g}$ with 0.12 pmol [125I] CHH ( 182,000 DPM) and unlabeled native $\mathrm{CHH}$ at 20 pmol for non-specific binding. No significant difference in $\mathrm{CHH}$ binding to the hepatopancreas was observed between the different ovarian stages, however, $\mathrm{CHH}$ binding to juvenile hepatopancreas was two times higher than to J-YO and the other tissues.
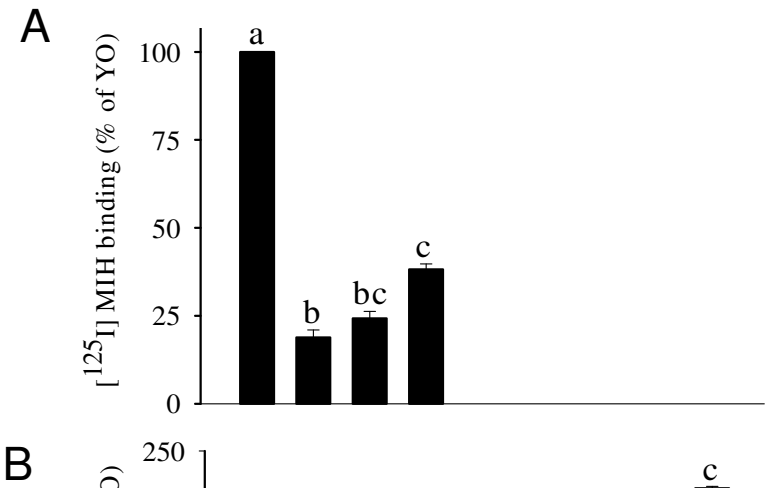

$\mathrm{B}$

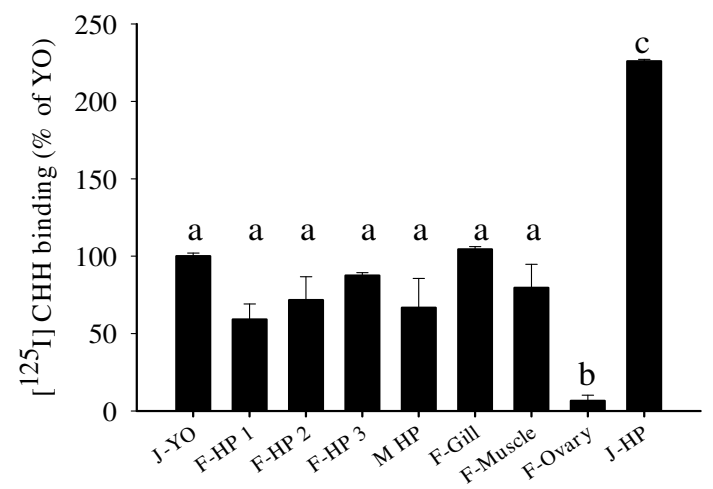

Tissue

Figure 2

MIH specifically binds to membranes of mature female hepatopancreas with higher binding at midvitellogenic stage than pre-vitellogenic. A) Specific binding of [ $\left.{ }^{\mid 25} \mid\right]$ MIH to various tissue membranes of vitellogenic females and $\mathrm{YO}$ and hepatopancreas of juveniles. $\mathrm{B}$ ) Specific binding of [ $\left.{ }^{125} \mid\right] \mathrm{CHH}$ to the same membranes. All membranes were prepared from five animals, except for JYO membranes that were prepared from 700 intermolt animals. F, Females; M, Males; J, juveniles; HP, hepatopancreas; I, 2, and 3 refer to the ovarian stages; F-ovary- ovarian membrane of females at ovarian stage 3. Results are presented as mean \pm SEM of the triplicates as $\%$ of the J-YO. The alphabetical letters show the significant differences at $P<0.05$. 
The ovaries exhibited a binding 20 times lower than J-YO (Fig. 2B).

A saturation curve was obtained by incubating 0.75 to 60 $\mathrm{nM}$ [125I] MIH with $100 \mu \mathrm{g}$ hepatopancreas membranes of ovarian stage 3 females (Fig. $3 \mathrm{~A}$ ). The calculated $\mathrm{K}_{\mathrm{D}}$ and $\mathrm{B}_{\mathrm{MAX}}$ values were $3.22 \times 10^{-8} \mathrm{M} / \mathrm{mg}$ protein and $9.24 \times 10^{-}$

${ }_{9}^{9} \mathrm{M} / \mathrm{mg}$ protein, respectively. Displacement studies were conducted using $0.04 \mathrm{nM}-100 \mathrm{nM}$ unlabeled rMIH as well as $12.5-100 \mathrm{nM}$ native $\mathrm{CHH}$. rMIH competed with [125I] MIH on the binding sites with an $\mathrm{EC}_{50}$ value of $17.35 \mathrm{nM}$, whereas $\mathrm{CHH}$ showed no displacement of [125I] MIH (Fig. 3B). The non-specific binding in these studies was $\sim 40 \%$ for $\mathrm{MIH}$ and $~ 30 \%$ for $\mathrm{CHH}$.

The plots obtained for MIH binding to the membranes of the J-YO and hepatopancreas were overlaid in order to demonstrate the difference in the affinities and the number of maximal binding sites (Fig. 4A and 4B). Calcu-

A

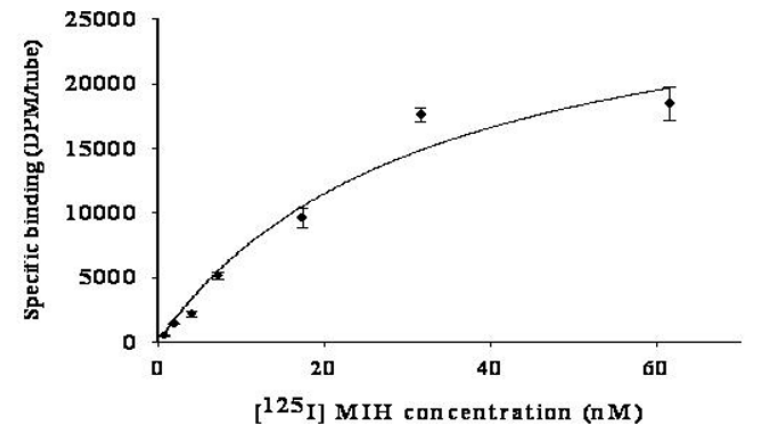

B

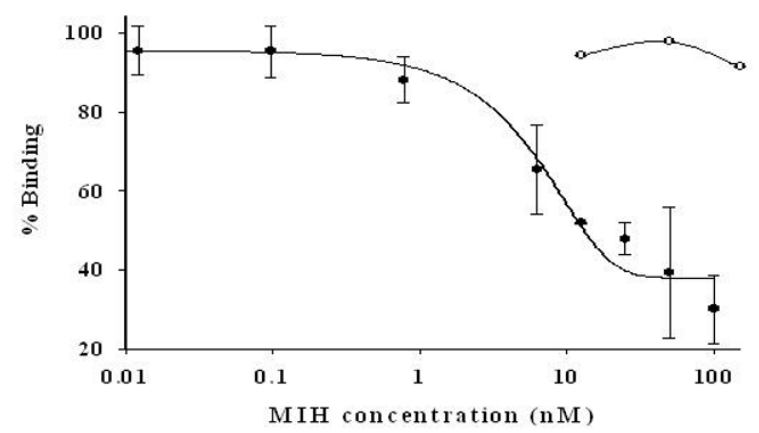

Figure 3

Kinetic binding studies of [125I] MIH to the hepatopancreas membranes of female $C$. sapidus at ovarian stage 3 demonstrate receptor/ligand typical and specific binding. Five membrane preparations were pooled and tested. A) Saturation curve; B) Displacement curve. [ $\left.{ }^{125 \mid}\right]$ MIH binding sites were displaced with unlabelled $\mathrm{rMIH}$ (closed circles) or unlabelled $\mathrm{CHH}$ (open circles). The data are presented as mean \pm SEM of the triplicates. lated $\mathrm{K}_{\mathrm{D}}$ values were $\sim 77$ times greater in the J-YO than female hepatopancreas: $4.19 \times 10^{-10}$ and $3.22 \times 10^{-8} \mathrm{M} / \mathrm{mg}$ protein, respectively. Values of $\mathrm{B}_{\operatorname{MAX}}$ were $9.24 \times 10^{-9} \mathrm{M} /$ mg protein for hepatopancreas and $4.80 \times 10^{-9} \mathrm{M} / \mathrm{mg}$ protein for J-YO.

\section{MIH and CHH effects on CAMP and CGMP levels in the hepatopancreas of vitellogenic females, in vitro}

The effects of MIH and CHH on levels of cAMP and cGMP production were tested in vitro in hepatopancreas fragments of vitellogenic females at ovarian early stage 2 (E2). As presented in Figs. 5A and 5B, CHH (20 nM) resulted in a 16 times increase in the levels of cGMP production (from 2 to $32 \mathrm{pmol} / \mathrm{mg}$ protein), while MIH at $2 \mathrm{nM}$ had no effect. Cyclic AMP levels did not change with $\mathrm{CHH}$, but increased by $50 \%$ in response to $2 \mathrm{nM} \mathrm{MIH} \mathrm{(from} 22$ to $33 \mathrm{pmol} / \mathrm{mg}$ protein, $\mathrm{N}=4$ ), compared to the control which received $1 \mathrm{mM}$ isobutylmethylxanthine (IBMX) alone (Fig. 5B).

A

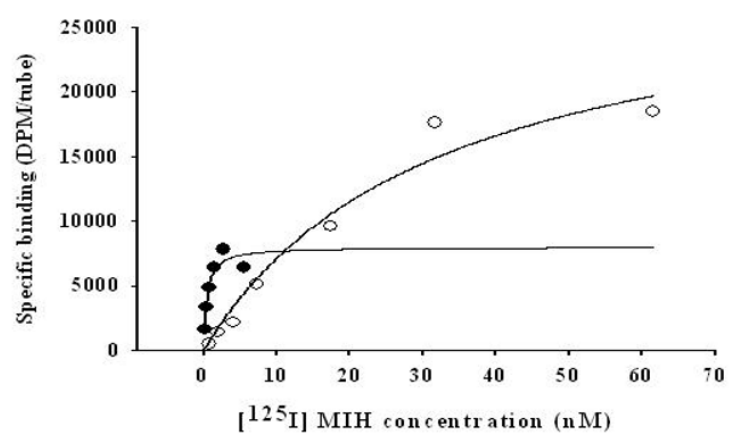

B

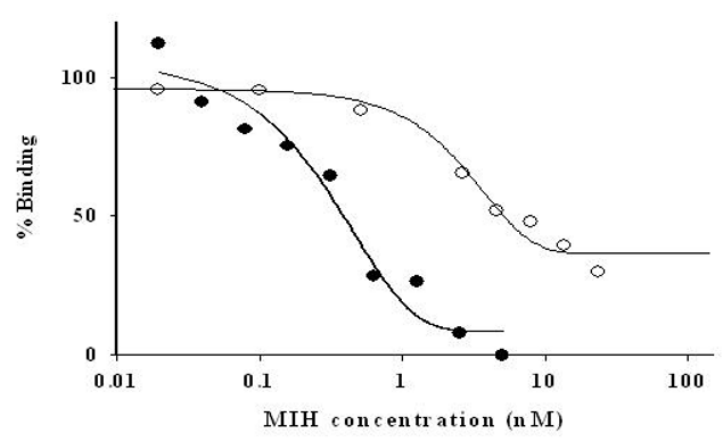

Figure 4

MIH binding to female hepatopancreas membranes is characterized by a lower affinity and higher density compared to juvenile YO. Overlay of the curves of saturation $(A)$ and displacement $(B)$ of $\left.\left[{ }^{125}\right]\right]$ MIH binding to YO and female hepatopancreas membranes to emphasize the differences in values of $K_{D}$ and $B_{M A X}$ between these tissues. YO, closed circles; hepatopancreas, open circles. 
A
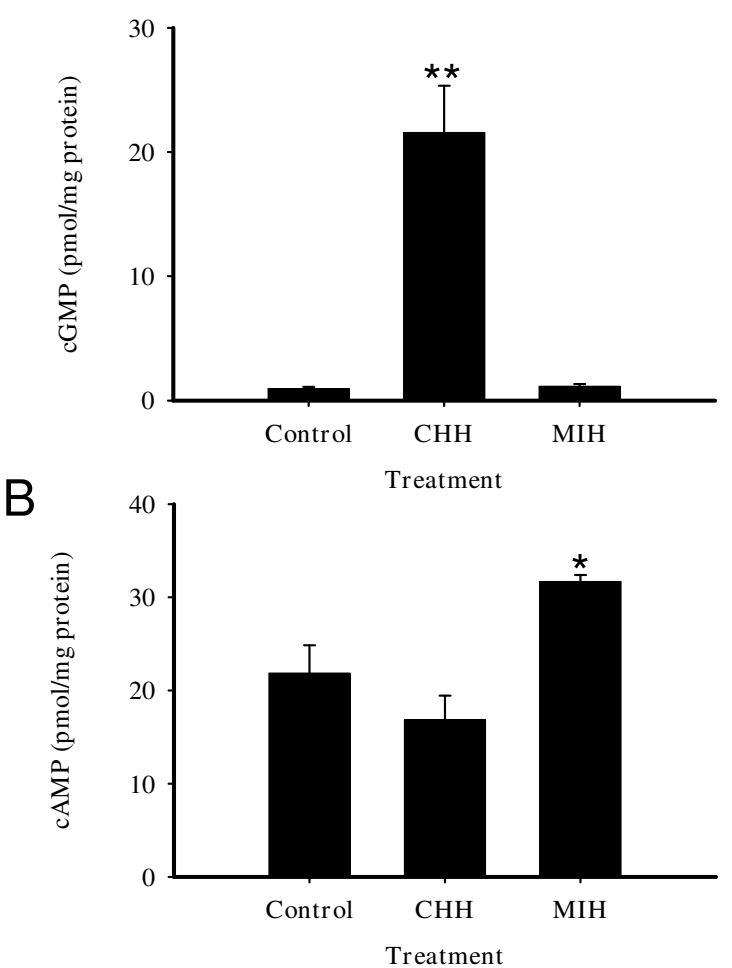

Figure 5

CHH induces cGMP and MIH induces CAMP production in female hepatopancreas fragments. In vitro: $A$ ) cGMP; B) cAMP. Hepatopancreas fragments were incubated with $20 \mathrm{nM} \mathrm{CHH}$ or $2 \mathrm{nM} M \mathrm{MH}$. The results are presented as mean $\pm \operatorname{SEM}(\mathrm{N}=4)$. $*, P \leq 0.05 ; * *, P \leq 0.01$.

The effects of cyclic nucleotide analogs on VtG transcriptions: hnVtG RNA and VtG mRNA

The incubation of hepatopancreas fragments at E2 with the membrane permeable 8 -Bromo-cAMP resulted in a $36 \%$ increase in the level of $h n V t G$ RNA, while 8-BromocGMP had no effect (Fig. 6). VtG mRNA in the hepatopancreas at E2 decreased to 50\% compared to the control with 8-Bromo-cAMP, whereas it remained constant with 8Bromo-cGMP (Fig. 6).

\section{Molecular weights of putative $\mathrm{MIH}$ receptors in the membranes of the YO and hepatopancreas of vitellogenic female}

YO and hepatopancreas membranes that were preincubated with [125I] MIH or hepatopancreas with [125I] $\mathrm{CHH}$ and crosslinked with disuccinimidyl suberate (DSS), were separated on SDS-PAGE and the signal was detected using a phosphorimager. Two bands were observed for each membrane: a lower one at the expected size of $\mathrm{MIH}$ (9070.9 Da) or CHH (8478.1 Da) [55]; and, a second higher band at an estimated size of $\sim 60 \mathrm{kDa}$ for MIH (Figs.

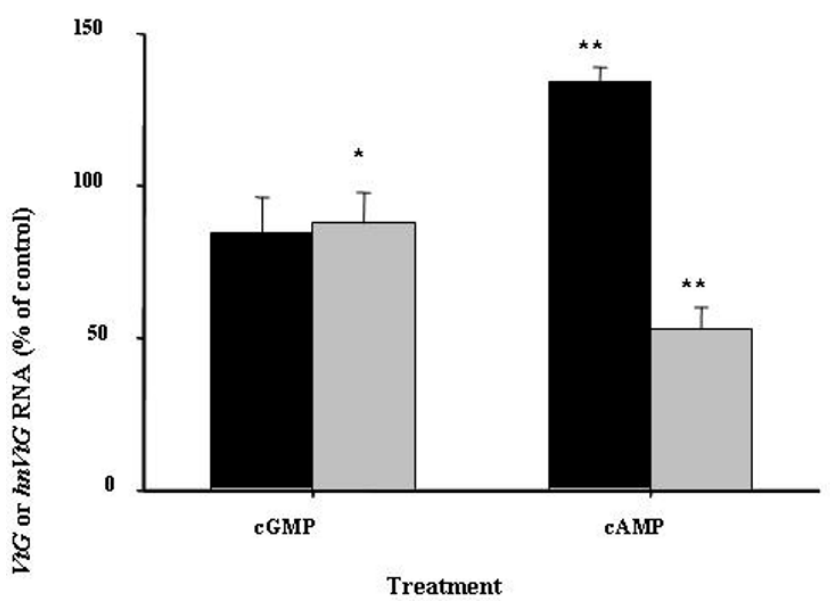

Figure 6

cGMP analog mimics the effects of $\mathrm{CHH}$ and CAMP analog mimics the effect of MIH on VtG mRNA and $h n V t G$ RNA in the hepatopancreas fragments of stage E2 females, respectively. Hepatopancreas fragments were incubated with $10 \mu \mathrm{M}$ 8-Bromo- cGMP or 8-Bromo- cAMP followed by QPCR analysis to detect changes in $h n V t G$ (Black) and $V t G$ mRNA (Grey). The results are presented as mean \pm SEM of $\%$ of control $(\mathrm{N}=4)$. *, $\mathrm{P} \leq 0.05$; **, $\mathrm{P} \leq 0.0 \mathrm{I}$.

$7 \mathrm{~A}$ and $7 \mathrm{~B}$ ). Binding of [125I] $\mathrm{CHH}$ to hepatopancreas membranes revealed a signal at a molecular weight of $\sim 70$ $\mathrm{kDa}$ (Fig. 7B). Assuming a binding ratio of 1 to 1 (ligand: receptor), the estimated size for the $\mathrm{MIH}$ receptor in both the YO and the hepatopancreas is $\sim 51 \mathrm{kDa}$ and $\sim 61 \mathrm{kDa}$ for the $\mathrm{CHH}$ receptor in the hepatopancreas.

\section{Discussion}

Based on our recent finding that $\mathrm{MIH}$ acts as a vitellogenesis stimulant in addition to its molt inhibitory function [12], we demonstrated in the current study the presence of specific binding sites for MIH in the J-YO membranes as well as novel binding sites in hepatopancreatic membranes of vitellogenic female $C$. sapidus. Kinetic studies revealed a specific, saturable, and non-cooperative binding indicative of a receptor-ligand interaction in both tissues, with differences in the affinity and density of the receptors between the two tissues. In addition, we have shown by crosslinking [125I] MIH to its receptor in the YO and hepatopancreas that the receptors are proteins with an estimated molecular weight of $\sim 51 \mathrm{kDa}$.

The radioligand receptor assays revealed that the presence of MIH specific binding sites in the hepatopancreas is found only in adult females and is vitellogenic stage- specific. Bound MIH in the hepatopancreas was specifically displaced by recombinant $\mathrm{MIH}$ (rMIH), but not by $\mathrm{CHH}$ (Fig. 3B). Moreover, MIH binding capacity in the hepatopancreas increased as ovarian stage advanced from 1 to 3 , 

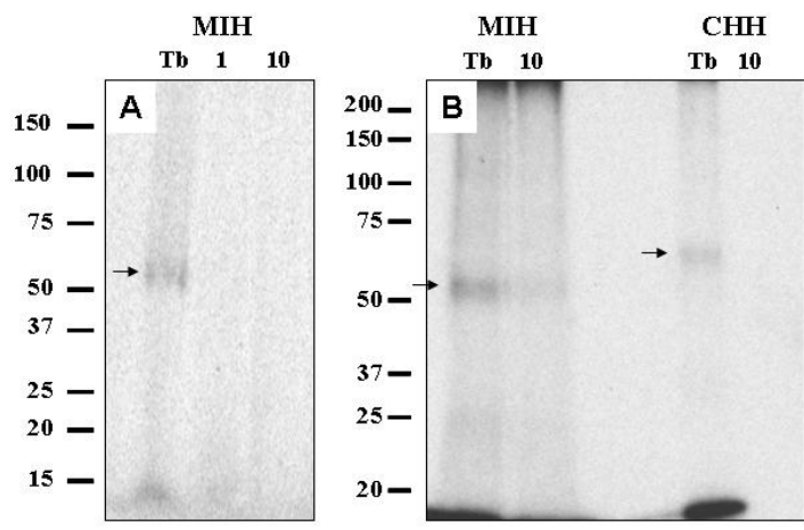

\section{Figure 7 \\ Binding sites of [125I] MIH in the membranes of female's hepatopancreas and juvenile $Y O$ have a sim- ilar molecular mass of $\sim 5 \mathrm{I} \mathbf{~ D D a}$, which is different from that of $\left[{ }^{125} \mid\right] \mathrm{CHH}$ in the hepatopancreas. A) J- YO (I00 $\mu \mathrm{g})$; B) female hepatopancreas at ovarian stage 3 $(200 \mu \mathrm{g})$. Membranes were incubated without (total binding, $\mathrm{Tb}$ ) or with unlabeled $\mathrm{MIH}$ or $\mathrm{CHH}$ in an excess of $\mathrm{I}$ or $\mathrm{IO}$ pmol, specified at the top of the lane. YO membranes were resolved on a 4-I5\% SDS-PAGE and hepatopancreas mem- branes on a 10\% SDS-PAGE. Labeled ligand and receptor complexes are indicated with arrows.}

reaching $\sim 40 \%$ of that of the J-YO binding, reflecting $\mathrm{B}_{\mathrm{MAX}}$ values $\left(4.8 \times 10^{-9}\right.$ and $9.24 \times 10^{-9} \mathrm{M} / \mathrm{mg}$ protein of $\mathrm{J}-\mathrm{YO}$ and hepatopancreas, respectively). The ovarian stage dependent increase of MIH binding in the hepatopancreas may be responsible for the ovarian stage dependent MIH effect on vitellogenesis[12]. In contrast, $\mathrm{CHH}$ binding was ubiquitous in the tissues tested except for ovary, as has been described in C. maenas [15]. Moreover, $\mathrm{CHH}$ binding in the hepatopancreas did not differ significantly between ovarian stages and sex (Fig. 2B). The $\mathrm{B}_{\mathrm{MAX}}$ value for $\mathrm{CHH}$ binding in the hepatopancreas of $\mathrm{C}$. sapidus was $3.67 \times 10^{-10} \mathrm{M} / \mathrm{mg}$ protein [18], similar to the value of $3.28 \times 10^{-10} \mathrm{M} / \mathrm{mg}$ protein obtained for hepatopancreas of C. maenas [15]. This suggests that at ovarian stage 3 , the number of MIH receptors in the hepatopancreas is the highest ever reported in the binding studies of the family of CHH neuropeptides, being 30 times higher than that of the $\mathrm{CHH}$ receptor. This high density of $\mathrm{MIH}$ receptors in hepatopancreas may cause higher non-specific binding than in the J-YO, as shown in Fig, 4B and Figs 7A and 7B. When considering the difference in size of the tissues between the J-YO $(\sim 20 \mathrm{mg})$ and the hepatopancreas $(\sim 7$ g) in adult females, the total number of MIH binding sites can easily be $\sim 700$ times higher in the hepatopancreas than in the YO.
As shown in Fig. 4, $\mathrm{K}_{\mathrm{D}}$ values of MIH binding sites in the $\mathrm{J}$-YO and female hepatopancreas membranes were significantly different: $4.19 \times 10^{-10}$ and $3.22 \times 10^{-8} \mathrm{M} / \mathrm{mg}$ protein, respectively. These values indicate that the affinity of the MIH receptor in the hepatopancreas is 77 times lower than that of the J-YO. Similar to what has been reported for $C$. maenas, $\mathrm{CHH}$ binding sites in the $\mathrm{YO}$ and hepatopancreas membranes had calculated $\mathrm{K}_{\mathrm{D}}$ values of $1.82 \times$ $10^{-9}$ and $6 \times 10^{-10} \mathrm{M} / \mathrm{mg}$ protein, respectively [17]. These affinities were comparable to those obtained for $\mathrm{MIH}$ binding sites in the J-YO $\left(4.19 \times 10^{-10} \mathrm{M} / \mathrm{mg}\right.$ protein $)$, all in the $0.1 \mathrm{nM} / \mathrm{mg}$ protein range. Thus, it seems that $\mathrm{MIH}$ binding sites in the hepatopancreas have the lowest affinity to its ligand among those of $\mathrm{CHH}$ neuropeptides characterized thus far. The low affinity of the hepatopancreas receptor may require high circulating titers of $\mathrm{MIH}$, with concentrations ranging from $0.01-20 \mathrm{nM}$ for binding (Fig. 3A). The level of MIH at ovarian stage 3 was $\sim 0.02$ $\mathrm{nM}[12]$, which was slightly higher than that of intermolt $(\sim 0.015 \mathrm{nM})$. Taken together, MIH receptor in the hepatopancreas is featured by low affinity-high binding capacity to its ligand (Fig. 4). The presence of different receptors for a ligand with different binding kinetics is well known for steroid receptors such as glucocorticoid receptor [56], peptides like gonadotropin-releasing hormone receptors [57], and polypeptide receptors such as prolactin receptor [58].

To determine whether the MIH signals through cGMP as a second messenger in the hepatopancreas as it does in the YO [38], we measured in vitro production of cyclic nucleotides in hepatopancreas fragments in the presence of 2 $\mathrm{nM} \mathrm{MIH}$ or $20 \mathrm{nM} \mathrm{CHH}$, which are effective doses in vitellogenesis [12]. As expected, intracellular cGMP levels in the hepatopancreas increased by 16 fold in response to $\mathrm{CHH}$, but did not change with MIH treatment (Fig. 5A). On the other hand, cAMP levels significantly increased by $50 \%$ with $\mathrm{MIH}$, but did not change with $\mathrm{CHH}$ treatment (Fig. 5B). The difference in the magnitude of response in the increase of cGMP (by CHH) compared to cAMP (by $\mathrm{MIH})$ may be due to different basal levels: cAMP, 20 $\mathrm{pmol} / \mathrm{mg}$ protein; $\mathrm{CGMP},<1 \mathrm{pmol} / \mathrm{mg}$ protein. Hepatopancreas fragments incubated with 8- Bromo-cAMP augmented $h n V t G$ RNA levels, while 8-Bromo-cGMP had no effect (Fig. 6). These findings are congruent with our previous results of no effect of $\mathrm{CHH}$ and the stimulatory effect of MIH on $h n V t G$ transcription at stage E2 [12]. Moreover, the membrane permeable 8-Bromo-cAMP and 8-Bromo-cGMP mimicked the effects of MIH and $\mathrm{CHH}$, respectively, on $V t G$ mRNA. $V t G$ mRNA significantly decreased by $60 \%$ with $\mathrm{MIH}$ and $20 \%$ with $\mathrm{CHH}$ in hepatopancreas fragments of ovarian stage E2 females[12].

The results obtained from the crosslinking studies showed that the complexes of MIH and its receptor in both the J- 
YO and the hepatopancreas have an estimated size of $~ 60$ $\mathrm{kDa}$, resulting in a MW of $\sim 51 \mathrm{kDa}$ for the receptor, which is different from that of the $\mathrm{CHH}$ receptor in the hepatopancreas (MW 61 kDa). Together with the second messenger data, this suggests that there is a tissue specific type of membrane receptor for $\mathrm{MIH}$, since only one band appeared in the autoradiogram in addition to the unbound neuropeptides (Figs. 7A and 7B). A similar study estimated the size of the MIH receptor in the YO of the kuruma prawn as $\sim 70 \mathrm{kDa}[16]$. Such a difference may lie in the difference in species.

The increase in intracellular cAMP in the hepatopancreas caused by MIH opposes the possibility that the receptor is a guanylate cyclase, and instead favors the option of a G protein - coupled receptor (GPCR) that acts through a GTP binding protein to activate a nucleotide cyclase. This agrees with the calculated $\mathrm{MW}$ of the hepatopancreas putative MIH receptor of $\sim 51 \mathrm{kDa}$, which is different from the typical membrane guanylate cyclase having a MW of 120-140 kDa [59]. In addition, the similarity in the MWs of MIH binding sites on the $\mathrm{YO}$ and hepatopancreas indicates that both MIH receptors may be GPCRs, however, each form may activate a different signaling pathway. A possible scenario is that the hepatopancreas MIH receptor activates the $\alpha_{s}$ subunit of the G protein-adenylyl cyclase, while the YO isoform activates soluble guanylyl cyclase through $\mathrm{Ca}^{2+}$ and $\mathrm{NO}^{-}$initiated by an increase in cAMP. Support for the latter option is found in a study reporting that incubation of the YO of C. maenas and P. clarkii at premolt stage with MIH resulted in a sustained 60 times increase in CGMP levels, and also a short, transient two fold increase in cAMP $[23,25]$. In addition, it was suggested that nitric oxide synthase and $\mathrm{NO}^{-}$are possibly involved in the MIH signaling in the $\mathrm{YO}$ of the land crab, Gecarcinus lateralis $[20,60]$. In this regard, the involvement of trimeric $G$ proteins in inhibition of protein synthesis in the $\mathrm{YO}$ of C. sapidus, was proposed [29]. Overall, the two suggested signaling pathways may involve a complex network of interactions and will require more rigorous investigations.

It was speculated that an extensive gene duplication event may have occurred to produce multiple $\mathrm{CHH}$ isoforms which may show tissue specific expression [61]. Similarly, receptors including the GPCR family members are believed to propagate by gene duplication from a common ancestor [62]. This includes odorant receptors [63], hormone receptors like growth hormone [64], gonadotrophins [65], gonadotrophin releasing hormones [66] and many more. Although the sequences of the MIH receptors in the current study are still unknown, these two receptors may possibly be products of gene duplication and share a high degree of structure similarity.
It is generally recognized that individual hormones can elicit several diverse responses in different organs and tissues, as well as in individual cells [14]. Several mechanisms may be involved in mediating the different signals such as 1) pulses and micropulses (frequency of changes of hormone circulation or endogenous concentrations); 2) changes in the activities of hormone-converting enzymes; 3 ) selective activation of each receptor type, subtype, and isoform; 4) changes in receptors, which may activate and suppress different signaling pathways (e.g. phosphorylation, dimerization); and 5) activation and suppression of different nuclear transcription processes [14]. The MIH receptor in the mature female's hepatopancreas is clearly different from the one present in the YO in terms of its time of appearance/functionality, its binding kinetics, and signal transduction. Thus, it fits some of the mechanisms mentioned above and provides a possible model for multi-functionality of the $\mathrm{CHH}$ neuropeptide family, which is based upon a diverse spatial and temporal expression, binding kinetics and signal transduction pathway. Based on this finding, we propose that some pleiotropicity of the $\mathrm{CHH}$ neuropeptide family might be mediated by multiple receptor forms: each form executes a different function.

\section{Conclusion}

In this study, we demonstrated the presence of novel specific MIH binding sites in the hepatopancreas of the mature female C. sapidus that are involved in MIH regulation of vitellogenesis. MIH action in the hepatopancreas is probably mediated by CAMP, unlike the YO counterpart that utilizes CGMP as a second messenger. Our result suggests that in the female $C$. sapidus, the antagonism between molting and reproduction is mediated by MIH that acquires a vitellogenesis stimulating function in addition to its traditional molt-inhibitory action. This new role is obtained through the expression of abundant MIH specific receptors in the hepatopancreas of the adult females. To our knowledge, this is the first description of an endocrine regulation mechanism of the antagonism between molting and reproduction in a crustacean species. As we proposed in Zmora et al. [12], this may occur in other crustaceans, particularly in those who share a similar life cycle with the female C. sapidus (i.e., a terminal molt upon puberty). It will be interesting to further examine how the two MIH receptors structurally differ and determine the specific timing and cues for the hepatopancreas MIH receptor appearance or activation.

\section{Methods \\ Animals}

Juvenile blue crabs at intermolt stage (carapace width 5$7.5 \mathrm{~cm}$ ) were collected by using a seine or a trot line from the eastern shore of the Chesapeake Bay [67]. Mature females obtained from a local waterman were transferred 
in aerated water and acclimated for 2 to 3 days without feeding in a 4.5 cubic meter re-circulating tank at ambient conditions. Tissue collection was carried out as described [68]. The tissues were dissected, rinsed in ice-cold crustacean saline and stored at $-80^{\circ} \mathrm{C}$ until further processing.

\section{Purification and quantification of native $\mathrm{CH}$, native $\mathrm{MIH}$, and recombinant $\mathrm{MIH}$}

Neuropeptides of the sinus glands (SG) and rMIH were purified using RP-HPLC as described [17]. Amino acid analyses were carried out for the quantification of the purified native $\mathrm{MIH}$, native $\mathrm{CHH}$ and $\mathrm{rMIH}$ using $o$ phthalaldehyde pre-column derivatization method as outlined [17].

\section{Radioligand binding assays}

Preparation of membranes

Membranes were prepared from 700 YO's collected from juvenile C. sapidus (J-YO, $5-7.5 \mathrm{~cm}$ carapace width) at intermolt stage (C4) by following the method as described [17]. Hepatopancreas membranes were prepared from individual females or males, using $\sim 1 \mathrm{~g}$ tissue. Each hepatopancreas or 700 pooled YO were homogenized in $20 \mathrm{ml}$ ice-cold homogenization buffer $(140 \mathrm{mM}$ $\mathrm{NaCl}, 300 \mathrm{mM}$ sucrose, $10 \mathrm{mM}$ HEPES, and $10 \mathrm{mM}$ benzamidine (Sigma), pH 7.4) using an Ultra Torax homogenizer. After an initial centrifugation at $1000 \mathrm{~g}$ for $5 \mathrm{~min}$ at $4^{\circ} \mathrm{C}$, the supernatant was pelleted by centrifugation at $30,000 \mathrm{~g}$ for $30 \mathrm{~min}$ at $4^{\circ} \mathrm{C}$. The pellet was washed in washing buffer (140 mM NaCl and 10 mM HEPES, pH 7.4 without BSA) by repeating the previous centrifugation step for $15 \mathrm{~min}$ and resuspending in the same buffer. Protein concentration was determined using a $D_{C}$ protein quantification kit (BioRad) and the membranes were aliquoted and stored at $-80^{\circ} \mathrm{C}$ until further use.

\section{$\mathrm{MIH}$ and $\mathrm{CH} \mathrm{H}$ binding studies}

\section{Binding assays}

Native [125I] MIH and native [125I] CHH were prepared using the chloramine-T labeling method as described [17] or using 1,3,4,6-tetrachloro-3alpha, 6alpha-diphenylglucoluril (iodogen) coated tubes (Pierce) according to the manufacturer's instruction. [125I] MIH or [125I] $\mathrm{CHH}$ was separated from free [125I] on a PD 10 column (GE Healthcare) as described [17]. Specific activities were approximately 300-500 Ci/mmol.

The MIH binding procedure was followed as stated [69]. Briefly, membranes were incubated in binding assay buffer (washing buffer containing 1\% BSA) with [125I] $\mathrm{MIH}$ or [125I] $\mathrm{CHH}$ for $1 \mathrm{~h}$ at room temperature. For displacement and non-specific binding, unlabeled native $\mathrm{CHH}$ or recombinant MIH (rMIH) produced in S2 Drosophila cells (Zmora et al. companion paper 1) was added to the reaction. The membranes were then washed in binding assay buffer and pelleted by centrifugation at $14,000 \mathrm{rpm}$ for $5 \mathrm{~min}$. The pellets were counted in a gamma-counter (HP counter). Each assay was repeated three or four times in triplicates.

\section{The effects of MIH and CHH on the levels of CAMP and cGMP, in vitro}

The hepatopancreas of vitellogenic females at stage E2 was excised and washed in 10 volumes of ice-cold Medium 199 (osmolarity $960 \mathrm{mmol} / \mathrm{kg}, 0.1 \mathrm{mg} / \mathrm{ml} \mathrm{BSA}$ and $1 \times$ protease inhibitors cocktail for tissue culture (Sigma), $\mathrm{pH}$ 7.4) for $3 \mathrm{~h}$ on ice, with three media changes as described [68]. Quantification of cAMP or cGMP in tissues using RIAs followed the procedure as described [70]. In brief, fragments of $10 \mathrm{mg}$ each were incubated for $1 \mathrm{~h}$ at room temperature in the presence of $2 \mathrm{nM} \mathrm{MIH}$ or $20 \mathrm{nM} \mathrm{CHH}$ in $400 \mu \mathrm{l}$ Medium 199 medium containing $1 \mathrm{mM}$ IBMX, or only IBMX for the control. The tissues were then disrupted by sonication (Branson) and centrifuged at 14,000 $\mathrm{rpm}$ for $10 \mathrm{~min}$ at $4^{\circ} \mathrm{C}$. Supernatants $(100 \mu \mathrm{l})$ were transferred to tubes containing $900 \mu \mathrm{l}$ of $0.1 \mathrm{M}$ acetate buffer ( $\mathrm{pH} 4.75)$ and immediately acetylated by the addition of $20 \mu \mathrm{l}$ triethylamine (Sigma) and $10 \mu \mathrm{l}$ acetic anhydride (Sigma). Fifty or one hundred $\mu$ l of acetylated samples were subjected to cAMP and cGMP RIAs. The standards for cAMP and CGMP in the range of 1-1000 fmol/tube were treated the same as the samples. The final dilution of antibodies was 1: 21,000 for CGMP and 1:4000 for cAMP.

2'-O-methyl ester cAMP or cGMP $(0.3 \mathrm{nmol})$ (Sigma) were iodinated with $\mathrm{Na}$ [125I] (Amersham) using the chloramine $\mathrm{T}$ method as described [70]. The iodinated material was separated from free [ $\left.{ }^{125} \mathrm{I}\right]$ on a $\mathrm{C}_{18}$ Sep-Pak cartridge (Waters) by elution with $40 \%$ isopropanol [71]. The calculated specific activities were approximately $500-$ $600 \mathrm{Ci} / \mathrm{mmol}$.

\section{The effects of membrane permeable analogues of CAMP} and cGMP on vitellogenin gene expression, in vitro

Hepatopancreas tissue was washed as described above and fragments of $10 \mathrm{mg}$ each were incubated in $400 \mu \mathrm{l}$ Medium199 medium containing $10 \mu \mathrm{M}$ 8-Bromo-cAMP or 8-Bromo-cGMP (Alexis) for 1 or $6 \mathrm{~h}$. RNA was extracted and the levels of $h n V t G$ RNA and $V t G$ mRNA were determined using quantitative PCR analysis (QPCR) analysis as described in Zmora et al. (companion paper 1).

\section{Crosslinking [ $\left.{ }^{|25|}\right] \mathrm{MIH}$ or ['25I] $\mathrm{CHH}$ to their binding sites and visualization}

Juvenile YO membranes $(100 \mu \mathrm{g})$ were incubated with 0.4 pmol [125I] MIH ( 263,000 DPM) for total binding or with additional 1 or $10 \mathrm{pmol} / 100 \mu \mathrm{l}$ unlabeled rMIH for nonspecific binding. The membranes were then washed twice with $1 \mathrm{ml}$ ice-cold washing buffer by centrifugation at $14,000 \mathrm{rpm}$ for $10 \mathrm{~min}$. The pellets were resuspended 
in $100 \mu \mathrm{l}$ buffer containing DSS (Pierce) at a final concentration of $1 \mathrm{mM}$ for $30 \mathrm{~min}$ at room temperature. The reaction was then quenched by the addition of $15 \mu \mathrm{l}$ of $1 \mathrm{M}$ Tris buffer ( $\mathrm{pH} \mathrm{7.4)}$ for $15 \mathrm{~min}$ at room temperature and centrifuged at 14,000 rpm for $5 \mathrm{~min}$. The pelleted membranes were resuspended in $1 \times$ SDS sample loading buffer (Bio-Rad) and denatured for $5 \mathrm{~min}$ at $100^{\circ} \mathrm{C}$. Proteins were separated on a 4-15\% SDS-PAGE and briefly stained with Bio-Safe coomassie (Bio-Rad) for visualization. The gel was then dried and exposed to a Phosphor-imager screen for $2 \mathrm{~h}$ at room temperature and analyzed using a Typhoon 9410 variable mode imager (Molecular Dynamics).

As for hepatopancreas membranes, the conditions described above were applied except that $200 \mu \mathrm{g}$ of the hepatopancreas membranes were incubated with $1 \mathrm{pmol}$ [125I] MIH ( 657,000 DPM) with or without 10 pmol cold MIH or 0.12 pmol [125I] CHH (182,500 DPM) and 10 pmol cold $\mathrm{CHH}$ for non-specific binding. After crosslinking with $5 \mathrm{mM}$ DSS, membranes were lysed by adding 4\% Triton X-100 for 10 min in binding buffer, followed by dilution to $1 \%$ Triton X-100. The sample was then immunoprecipitated with $4 \mu \mathrm{l} \mathrm{MIH}$ antiserum for 1 $\mathrm{h}$ at $4{ }^{\circ} \mathrm{C}$, followed by the addition of protein-A magnetic beads (New England Biolabs) to the mixture and incubated for an additional hour. Bound proteins were separated via a magnet apparatus and eluted with $3 \times$ SDS sample loading buffer. After heating at $70^{\circ} \mathrm{C}$ for $3 \mathrm{~min}$, the samples were run on a $10 \%$ SDS PAGE. The gel was dried and analyzed as described above.

\section{Statistical analysis}

The results obtained from the radioligand binding studies are presented for each experiment as the mean \pm SEM of the experimental replicates. The data obtained from QPCR analysis and RIA are presented as mean \pm SEM for the separate experiments. The results were subjected to GraphPad Instat 3 program analysis (Graphpad) and were examined using one-way ANOVA followed by the TukeyKramer multiple comparison test. In all cases, statistical difference was accepted at $\mathrm{P} \leq 0.05$.

\section{Abbreviations}

MIH: molt-inhibiting hormone; $\mathrm{CHH}$ : crustacean hyperglycemic hormone; QPCR: quantitative PCR; $V t G$ : vitellogenin mRNA; VtG: vitellogenin protein; cAMP: 3'-5'-cyclic adenosine monophosphate; cGMP; 3'-5'-cyclic guanosine monophosphate.
\end{abstract}

\section{Competing interests}

The authors declare that they have no competing interests.

\section{Authors' contributions}

NZ carried out the concept, experimental design, and acquisition, analyses, and interpretation of data, and drafted and revised the manuscript including tables and figures. CJS was involved in the acquisition of funding, contributed to concept, experimental design, analyses, and interpretation of data, and revised the manuscript. AS participated in the discussions and revision of the manuscript. YZ was involved in the acquisition of funding and contributed in discussions.

All authors read and approved the final manuscript.

\section{Acknowledgements}

This research was supported by the National Oceanic and Atmospheric Administration (NOAA), Chesapeake Bay Program Grant (NAI7FU284I) to the Blue Crab Advanced Research Consortium. We would like to thank Mr. Mark Saltis for his help and dedication in catching juvenile crabs. We are indebted to Professor J. deVante (Maastricht University) for his generous gifts of CAMP and cGMP antisera. This is the Center of Marine Biotechnology's contribution number $08-182$.

\section{References}

I. Chan SM, Gu PL, Chu KH, Tobe SS: Crustacean neuropeptide genes of the $\mathrm{CHH} / \mathrm{MIH} / \mathrm{GIH}$ family: implications from molecular studies. Gen Comp Endocrinol 2003, 134:214-219.

2. De Klein DPV, Van Herp F: Molecular biology of neurohormone precursors in the eyestalk of crustacea. Comp Biochem Physiol $B$ Biochem Mol Biol. 1995, I I 2(4):573-579.

3. Keller R: Crustacean neuropeptides: structure, functions and comparative aspects. Experientia 1992, 48:439-448.

4. Spanings-Pierrot C, Soyez D, Van-Herp F, Gompel M, Skaret G, Grousset E, Charmantier G: Involvement of crustacean hyperglycemic neurohormone in the control of gill ion transport in the crab Pachygrapsus marmoratus. Gen Comp Endocrinol 2000, I 1 9:340-350.

5. Spanings-Pierrot C, Bisson L, Towle D: Expression of a crustacean hyperglycemic hormone isoform in the shore crab, Pachygrapsus marmoratus, during adaptation to low salinity. Bull Mount Desert Island Biol Lab 2005, 44:67-69.

6. Chung JS, Dircksen H, Webster SG: A remarkable, precisely timed release of hyperglycemic hormone from endocrine cells in the gut is associated with ecdysis in the crab Carcinus maenas. Proc Natl Acad Sci USA 1999, 96(23): I3 I03-13107.

7. Böcking $D$, Dircksen $H$, Keller R: The crustaceans neuropeptides of the CHH/MIH/GIH family. In The Crustacean Nervous System Edited by: Wiese K. Springer; 2002:84-97.

8. Hsu YW, Messinger DI, Chung JS, Webster SG, De la Iglesia HO, Christie AE: Members of the crustacean hyperglycemic hormone $(\mathrm{CHH})$ peptide family are differentially distributed both between and within the neuroendocrine organs of Cancer crabs: implications for differential release and pleiotropic function. J Exp Biol 2006, 209( 16):324I-3256.

9. Abramowitz A, Hisaw F, Papandrea D: The occurrence of a diabetogenic factor in the eyestalks of crustaceans. Biol Bull 1944 , 86: I-4.

10. Chang ES: Crustacean hyperglycemic hormone family: Old paradigms and new perspectives. Amer Zool 200I, 4I:380-388.

II. Khayat M, Yang W, Aida K, Nagasawa H, Tietz A, Funkenstein B, Lubzens $E$ : Hyperglycaemic hormones inhibit protein and mRNA synthesis in in vitro-incubated ovarian fragments of the marine shrimp Penaeus semisulcatus. Gen Comp Endocrinol 1998, II 0(3):307-318.

12. Zmora N, Trant J, Zohar Y, Chung J: Molt-inhibiting hormone stimulates vitellogenesis at advanced ovarian developmental stages in the female blue crab, Callinectes sapidus: an ovarian stage dependent involvement. Saline Systems. 2009, 5(I):7.

13. Tiu SH, Chan SM: The use of recombinant protein and RNA interference approaches to study the reproductive functions 
of a gonad-stimulating hormone from the shrimp Metapenaeus ensis. FEBS J 2007, 274(17):4385-4395.

14. Mandoki JJ, Mendoza-Patiño N, Molina-Guarneros JA, Jiménez-Orozco FA, Velasco-Velázquez MA, García-Mondragón MJ: Hormone multifunctionalities: a theory of endocrine signaling, command and control. Prog Biophys Mol Biol 2004, 86(3):353-377.

15. Chung JS, Webster SG: Binding sites of crustacean hyperglycemic hormone and its second messengers on gills and hindgut of the green shore crab, Carcinus maenas: A possible osmoregulatory role. Gen Comp Endocrinol 2006, 147:206-2I3.

16. Asazuma H, Nagata S, Katayama H, Ohira T, Nagasawa H: Characterization of a molt inhibiting hormone (MIH) in the Y-organ of the kuruma prawn, Marsupenaeus japonicus. Ann N Y Acad Sci 2005, 1040:215-218

17. Webster SG: High-affinity binding of putative moult-inhibiting hormone (MIH) and crustacean hyperglycemic hormone (CHH) to membrane bound receptors on the $Y$ - organ of the shore crab Carcinus maenas. Proc R Soc Lond, B, Biol Sci 1993, B 25I:53-59.

18. Katayama H, Chung JS: The specific binding sites of eyestalkand pericardial organ-crustacean hyperglycaemic hormones (CHHs) in multiple tissues of the blue crab, Callinectes sapidus. J Exp Biol. 2009, 212 (Pt 4):542-549.

19. Imayavaramban L, Dhayaparan D, Devaraj H: Molecular mechanism of molt-inhibiting hormone (MIH) induced suppression of ecdysteroidogenesis in the Y-organ of mud crab: Scylla serrata. FEBS lett 2007, 58 I(27):5।67-5172.

20. Lee SG, Mykles DL: Proteomics and signal transduction in the crustacean molting gland. Integr Comp Biol 2006, 46(6):965-977.

21. Mattson MP, Spaziani E: Cyclic AMP mediates the negative regulation of Y-organ ecdysteroid production. Mol Cell Endocrinol 1985, 42: 185-189.

22. Mattson MP, Spaziani E: Regulation of Y-organ ecdysteroidogenesis by molt-inhibiting hormone in crabs: involvement of cyclic AMP-mediated protein synthesis. Gen Comp Endocrinol 1986, 63(3):4|4-423.

23. Nakatsuji T, Han DW, Jablonsky MJ, Harville SR, Muccio DD, Watson RD: Expression of crustacean (Callinectes sapidus) molt-inhibiting hormone in Eschrichia coli: Characterization of the recombinant peptide and assessment of its effects on cellular signaling pathways in Y-organs. Mol Cell Endocrinol 2006, 253:96-104.

24. Okumura T: Effects of cyclic nucleotids, calcium ionophore, and phorbol ester on vitellogenin mRNA levels in incubated ovarian fragments of the kuruma prawn Marsupenaeus japonicus. Gen Comp Endocrinol 2006, I 48:245-25I.

25. Saidi B, De Besse N, Webster SG, Sedlmeier D, Lachaise F: Involvement of CAMP and CGMP in the mode of action of moltinhibiting hormone (MIH) a neuropeptide which inhibits steroidogenesis in a crab. Mol Cell Endocrinol 1994, 102:53-61.

26. Sedlmeier $D$, Fenrich R: Regulation of ecdysteroid biosynthesis in crayfish Y-organs I. Role of cyclic nucleotides. J Exp Zool 1993, 265:448-453.

27. von Gliscynski U, Sedlmeier D: Regulation of ecdysteroid biosynthesis in crayfish Y-organ II. Role of cyclic nucleotidedependent protein kinases. J Exp Zool 1993, 265:454-458.

28. Zheng J, Nakatsuji T, Roer RD, Watson RD: Studies of a receptor guanylyl cyclase cloned from the blue crab (Callinectes sapidus), and its possible functional link to ecdysteroidogenesis. Gen Comp Endocrinol 2008, I55:780-788.

29. Han DW, Watson RD: Trimeric G proteins in crustacean (Callinectes sapidus) Y-organs: Occurrence and functional link to protein synthesis. J Exp Zoolog A Comp Exp Biol. 2005, 303(6):44I-447.

30. Lee SG, Bader BD, Chang ES, Mykles DL: Effects of elevated ecdysteroid on tissue expression of three guanylyl cyclases in the tropical land crab Gecarcinus lateralis: possible roles of neuropeptide signaling in the molting gland. J Exp Biol 2007, 21 0( I 8):3245-3254

31. Zheng J, Lee CY, Watson RD: Molecular cloning of a putative receptor guanylyl cyclase from Y-organs of the blue crab, Callinectes sapidus. Gen Comp Endocrinol 2006, I 46(3):329-336.

32. Webster SG, Keller R: Purification, characterization and amino acid composition of the putative moult-inhibiting hormone (MIH) of Carcinus maenas (Crustacea, Decapoda). J Comp Physiol 1985, 156:617-624.
33. Webster SG: Neuropeptides inhibiting growth and reproduction in crustaceans. In Recent Advances in Arthropod Endocrinology Edited by: Coast GM, Webster SG. Cambridge: Cambridge University Press; 1998:33-52.

34. Skinner DM: Molting and regeneration. In The Biology of Crustacea Volume 9. Edited by: Bliss DE, Mantel LH. New York: Academic press; 1985:43-I46.

35. Chang ES, O'Connor JD: Crustacea: molting. In Endocrinology of Selected Invertebrate Types Edited by: Laufer L, Downer RGH. New York: Liss, A R; 1988:259-278.

36. Watson RD, Spaziani E, Bollenbacher WE: Regulation of ecdysone biosynthesis in insects and crustaceans: a comparison. In Ecdysone Edited by: Koolman J. New York: Thieme Medical Publisher; 1989:188-203

37. Sefiani M, Le Caer JP, Soyez D: Characterization of hyperglycemic and molt-inhibiting activity from sinus glands of the penaeid shrimp Penaeus vannamei. Gen Comp Endocrinol 1996, 103:4I-53.

38. Chung JS, Webster SG: Moult cycle-related changes in biological activity of moult-inhibiting hormone (MIH) and crustacean hyperglycaemic hormone (CHH) in the crab Carcinus maenas. Eur J Biochem 2003, 270:3280-3288.

39. Nakatsuji T, Sonobe $H$, Watson RD: Molt-inhibiting hormone mediated regulation of ecdysteroid synthesis in $\mathrm{Y}$-organs of the crayfish (Procambarus clarkii). Mol Cell Endocrinol 2006, 253:76-82.

40. Goy MF: Activation of membrane guanylate cyclase by an invertebrate peptide hormone. I Biol Chem 1990, 265(33):20220-20227.

4I. Macins A, Meredith J, Zhao Y, Brock HW, Phillips JE: Occurrence of ion transport peptide (ITP) and ion transport-like peptide (ITP-L) in orthopteroids. Arch Insect Biochem Physiol 1999, 40(2): $107-118$.

42. De Klein DPV, Van Herp F: Involvement of the hyperglycemic neurohormone family in the control of reproduction in decapod crustaceans. Invert Reprod Dev 1998, 33:263-272.

43. Sarojini R, Mirajkar MS, Nagabhushanam R: Bihormonal control of oogenesis in the freshwater prawn, Macrobrachium kistnensis. Acta Physiol Hung 1983, 6 I (I-2):5-12.

44. Chaves AR: Effect of x-organ sinus gland extract on [(35)S] methionine incorporation to the ovary of the red swamp crawfish Procambarus clarkii. Comp Biochem Physiol, Part A Mol Integr Physiol 2000, I 26:407-4I3.

45. Bomirski A, Klek-Kawi'nska E: Ovary-inhibiting hormone activity in shrimp (Crangon crangon) eyestalks during the annual reproductive cycle. Gen Comp Endocrinol 1975, 25(I):9-13.

46. Fingerman $\mathrm{M}$ : Roles of neurotransmitters in regulating reproductive hormone release and gonadal maturation in decapod crustaceans. Invertebr Reprod Dev 1997, 3 I:47-54.

47. Yano I, Tsukimura B, Sweeney JN, Wyban JA: Induced ovarian maturation of Paneaus vannamei by implantation of lobster ganglion. J World Aquac Soc 1988, I 9(4):204-208.

48. Ohira T, Okumura T, Suzuki M, Yajima Y, Tsutsui N, Wilder M, Nagasawa $\mathrm{H}$ : Production and characterization of recombinant vitellogenesis-inhibiting hormone from the American lobster Homarus americanus. Peptides 2006, 27:125।-1258.

49. Edomi P, Azzoni E, Mettulio R, Pandolfelli N, Ferrero AE, Giulianini P: Gonad-inhibiting hormone of the Norway lobster (Nephrus norvegicus). Gene 2002, 284:93-102.

50. De Klein DPV, Sleutels FJGT, Martenz GJM, Van Herp F: Cloning and expression of mRNA encoding prepro-gonad-inhibiting hormone (GIH) in the lobster Homarus americanus. FEBS letters 1994, 353:255-258.

51. Ollivaux C, Vinh J, Soyez D, Toullec JY: Crustacean hyperglycemic and vitellogenesis-inhibiting hormones in the lobster Homarus gammarus. FEBS J 2006, 273(I0):215I-2160.

52. Tsutsui N, Ohira T, Kawazoe I, Takahashi A, Wilder MN: Purification of sinus gland peptides having vitellogenesis-inhibiting activity from the whiteleg shrimp Litopenaeus vannamei. Mar Biotechnol (NY). 2007, 9(3):360-369.

53. Greve P, Sorokine O, Berges T, Lacombe C, Van Dorsselaer A, Martin G: Isolation and amino acid sequence of a peptide with vitellogenesis inhibiting activity from the terrestrial isopod Armadillidum vulgare (Crustacea). Gen Comp Endocrinol 1999, | | 5:406-4|4 
54. Yano I: Ultraintensive culture and maturation in captivity of penaeid shrimp. In CRC Handbook of Mariculture: Crustacean Aquaculture 2nd edition. Edited by: McVey JP. Boca Raton, Florida: CRC Press; 1993:289-3। 3.

55. Chung JS, Zmora N: Functional studies of crustacean hyperglycemic hormones (CHHs) of the blue crab, Callinectes sapidus: the expression and release of $\mathrm{CHH}$ in eyestalk and pericardial organ in response to environmental stress. FEBS J 2008, 275(4):693-704.

56. Howell GM, Gustafsson JA, Lefebvre YA: Glucocorticoid receptor identified on nuclear envelopes of male rat livers by affinity labeling and immunochemistry. Endocrinology. 1990, 127(3): 1087-1096.

57. Murthy CK, Wong AOL, Habibi HR, Rivier JE, Peter RE: Receptor binding of gonadotropin-releasing hormone antagonists that inhibit release of gonadotropin-II and growth hormone in goldfish, Carassius auratus. Biol Reprod 1994, 5 I (3):349-357.

58. Odd B, Charles SN: Effects of prolactin, growth hormone, and triiodothyronine on prolactin receptors in larval and adult tiger salamanders (Ambystoma tigrinum). J Exp Zool 1993, 266(4):290-298.

59. Drewett JG, Garbers DL: The family of guanylyl cyclase receptors and their ligands. Endocr Rev 1994, I 5(2): I35-162.

60. Kim HW, Batista LA, Hoppes JL, Lee KJ, Mykles DL: A crustacean nitric oxide synthase expressed in nerve ganglia, $Y$ organ, gill and gonad of the tropical land crab, Gecarcinus lateralis. J Exp Biol 2004, 207:2845-2857.

6I. Kwok R, Chan SM, Martinez-Perez F, Zinker S, Tobe SS: Crustacean chromatophorotrophines and hyperglycemic hormone peptide families. In Handbook of Biologically Active Peptides Edited by: Kastin AJ. Academic Press; 2006:229-332.

62. Perez DM: The evolutionarily triumphant G-protein-coupled receptor. Mol Pharmacol 2003, 63:1202-1205.

63. Guo S, Kim J: Molecular evolution of drosophila odorant receptor genes. Mol Biol Evol 2007, 24:I 198-1207.

64. Saera-Vila A, Calduch-Giner JA, Perez-Sanchez J: Duplication of growth hormone receptor (GHR) in fish genome: gene organization and transcriptional regulation of GHR type I and II in gilthead sea bream (Sparus aurata). Gen Comp Endocrinol 2005, I42(I-2): 193-203.

65. Heckert LL, Daley IJ, Griswold MD: Structural organization of the follicle-stimulating hormone receptor gene. Mol Endocrinol 1992, 6:70-80.

66. Moncaut N, Somoza G, Power DM, Canário AVM: Five gonadotrophin-releasing hormone receptors in a teleost fish: isolation, tissue distribution and phylogenetic relationships. J Mol Endocrinol. 2005, 34(3):767-779.

67. Drach P: Mue et cycle d'intermue chez les Crustacés Décapodes. Ann Inst Oceanogr Monaco, N S 1939, 19:103-391.

68. Zmora N, Trant MJ, Chan SM, Chung JS: Vitellogenin and its messenger RNA during ovarian development in the female blue crab, Callinectes sapidus: Gene expression, synthesis, transport, and cleavage. Biol Reprod 2007, 77:138-146.

69. Chung JS, Webster SG: Does N-terminal pyroglutamate residue have any physiological significance for crab hyperglycemic neuropeptides? Eur J Biochem 1996, 240:358-364.

70. Goldsworthy GJ, Chung JS, Simmonds MS, Tatari M, Varouni S, Poulos CP: The synthesis of a stable analogue of the locust CRF-like diuretic peptide, and the biological activities of this and some C-terminal fragments. Peptides 2003, 24:1607-1613.

71. Chung JS, Webster SG: Dynamics of in vitro release of moltInhibiting hormone and crustacean hyperglycemic hormone in the shore crab, Carcinus maenas. Endocrinol 2005, I 46:5545-555I.

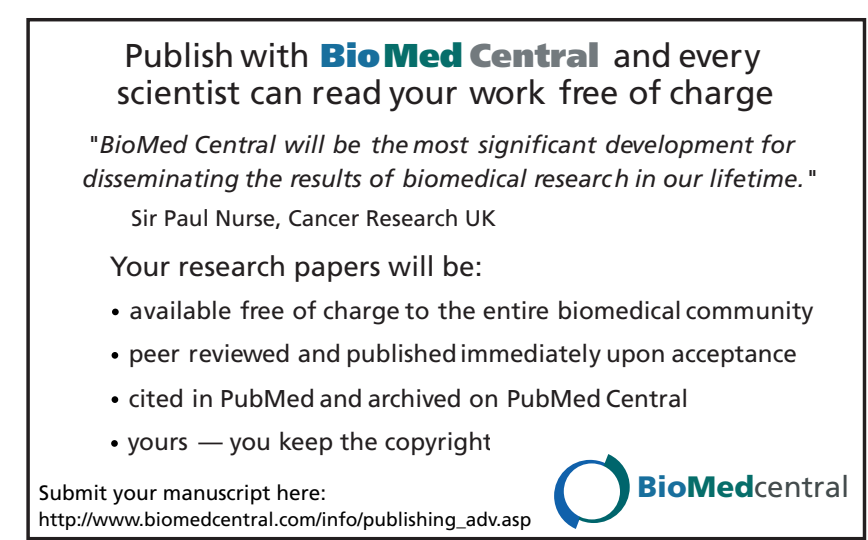

